\title{
May titanium spiral tacks contribute to intra-abdominal adhesion formation? ${ }^{1}$
}

Grampos espirais de titânio podem contribuir para a formação de aderências intra-abdominais?

\begin{abstract}
Alberto Goldenberg, Carlos Eduardo Rivas", Gustavo Schvartsman'II
IPhD, Associate Professor, Surgical Gastroenterology Division, Department of Surgery, Paulista School of Medicine (EPM), Federal University of Sao Paulo, (UNIFESP), Brazil. Conception, design, intellectual and scientific content of the study, manuscript writing and final revision.

${ }^{I I M D}$, Volunteer, Surgical Gastroenterology Division, Department of Surgery, EPM/UNIFESP, Sao Paulo-SP, Brazil. Helped with technical procedures, collection and processing study informations.

IIIGraduate student, Scientific Initiation Program (PIBIC), Surgical Gastroenterology Division, Department of Surgery, EPM/UNIFESP, Sao Paulo-SP, Brazil. Involved with technical procedures and acquisition of data.
\end{abstract}

\begin{abstract} RESULTS: No adhesion was found where the titanium spiral tacks were placed.

CONCLUSION: Titanium spiral tacks for fixation do not cause adhesions in rabbits.

Key words: Titanium. Surgical Fixation Devices. Tissue Adhesions. Rabbits.
\end{abstract}

PURPOSE: To verify if titanium spiral tacks may contribute to intra-abdominal adhesion formation in rabbits.

METHODS: Ten New Zealand white rabbits were used. Through videolaparoscopic surgery two titanium spiral tacks (ProTack ${ }^{\circledR}$, Covidien $^{\circledR}$ ) were applied in the right flank. After 30 days the animals were submitted to evaluate peritoneal cavity by videolaparoscopy.

\section{RESUMO}

OBJETIVO: Verificar se grampos espirais de titânio podem contribuir para a formação de aderências intra-abdominais em coelhos. MÉTODOS: Foram utilizados 10 coelhos albinos linhagem Nova Zelândia. Por meio de vídeo laparoscopia foram aplicados dois grampos metálicos espirais de titânio (ProTack ${ }^{\circledR}, \operatorname{Covidien}^{\circledR}$ ) na região do flanco direito. Após 30 dias, os animais foram submetidos à laparoscopia para avaliação da cavidade peritoneal.

RESULTADOS: Não foi encontrada nenhuma aderência aos grampos aplicados.

CONCLUSÃO: Os grampos em espiral de titânio para a fixação não causam aderências em coelhos.

Descritores: Titânio. Dispositivos de Fixação Cirúrgica. Aderências Teciduais. Coelhos. 


\section{Introduction}

Inflammatory response and adhesions formation of synthetic mesh prostheses inserted inside peritoneal cavity has been our research line ${ }^{1-3}$.

Other authors bring into question if adhesions are provoked by prostheses or by the fixation procedure.

Karahasanoglu et $a l .{ }^{4}$ compared formation of adhesions between titanium spiral tacks and suture to fixed mesh in pigs, showing significant incidence of adhesion with the metallic tacks.

Eriksen et al..$^{5}$ compared the fixation of mesh with fibrin sealant and titanium in pigs. They did not find statistic significant differences in adhesions.

Gungor et $a l .{ }^{6}$ realized a comparative evaluation of adhesions on intraperitoneal fixation materials by a laparoscopic study in rats. They observed that after 15 days adhesions were greater with nickel titanium clips than with polilactic acid stitches or with titanium spiral tacks. No adhesions with fibrin sealant were found.

In general prostheses are fixed with metallic tacks.

Authors observed the formation of adhesions with permanent mesh fixation devices s, $^{4,7,8}$.

Our goal is to investigate if titanium spiral tacks may contribute to intra-abdominal adhesion formation in rabbits.

\section{Methods}

Ten New Zealand (Oryctolagus cuniculus) white rabbits, three month age, weighting between 2000 and 2500g, were used.

This investigation was approved by the Committee of Ethics in Research with animals of Albert Einstein Teaching and Research Institute, cared by specialized veterinarians.

The surgical procedures were done at the experimental laboratory of this Institute.

All rabbits were kept in abstinence from food for 12 hours and under standard conditions.

Anesthesia was induced using intramuscular acepromazina (Acepran ${ }^{\circledR} 1 \%$ ) ten minutes before the procedure. Then, intramuscular ketamine plus xylazine were used.

Abdominal wall was completely clipped and disinfected with povidone-iodine and all procedures were performed under sterile technique.

A periumbilical incision $(1 \mathrm{~cm})$ was made to craft pneumoperitoneum using a Verres needle puncture $(8 \mathrm{mmHg}$ steady pressure). Two $5 \mathrm{~mm}$ trocars were placed: $30^{\circ}$ scope (umbilical incision) and tacker device (left flank).
Titanium spiral tacks $\left(\right.$ ProTack $^{\circledR}$, Covidien $^{\circledR}$ ) were used. Two titanium spiral tacks were applied in the right flank.

Aponeurosis was closed with poligalactine 2-0 and skin with nylon 4-0. The peritoneum was left open.

After recovery, animals returned to their cages with food and water ad libitum, with daily follow up for 30 days.

All events were registered. After the period of observation the animals were anesthetized again and submitted to a new videolaparoscopy procedure to find the occurrence of adhesions.

A periumbilical incision $(1 \mathrm{~cm})$ was made to craft pneumoperitoneum using a Verres needle puncture $(8 \mathrm{mmHg}$ steady pressure). A $5 \mathrm{~mm}$ trocar was placed and introduced a $5 \mathrm{~mm}$ $30^{\circ}$ scope.

Abdominal cavity was evaluated and tacker's sites investigated.

The whole procedure was documented.

After laparoscopy the animals were euthanized by anesthetic drugs.

\section{Results}

All animals had good postoperative recovery without any complications.

The duration of surgeries was between 10 and 20 minutes with no difficulty to place the tacks.

No adhesions were observed through laparoscopy where the clips were implanted (Figure 1).
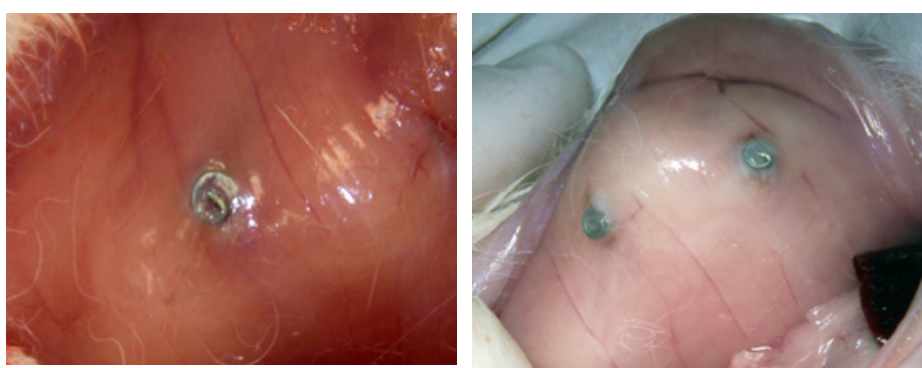

FIGURE 1 - No adhesion found and peritonealization of the titanium tacks was observed.

\section{Discussion}

Mesh fixation in abdominal cavity is important to avoid dislocation ${ }^{7}$, but may cause adhesions ${ }^{8}$.

There are few studies about fixation materials without the presence of prostheses ${ }^{6}$.

Non-use of prosthesis takes away the influence of adhesions formation.

Our experimental studies always observed important 
adhesions with prostheses in contact with viscera, independent of the type and protection of the mesh ${ }^{1-3}$.

Rabbits are used in research to evaluate types of mesh and it is a satisfactory biological model ${ }^{1-3}$.

Authors that studied mesh fixation and respective adhesions used prosthesis, that difficults conclusions $\mathrm{s}^{4,6,7,8}$.

Only one author studied four different types of fixation without the use of meshes in rats ${ }^{6}$.

We applied two titanium spiral tacks in each animal simulating fixation of the mesh.

The clips were positioned in the same place and both were near each other.

Thirty days are enough to evaluate adhesions formation. We did not find any adhesions at this time.

Adhesions find in our previous studies must be considered due to prosthesis other than to the fixation procedure.

\section{Conclusion}

Titanium spiral tacks do not contribute to intra-abdominal adhesion formation in rabbits.

\section{References}

1. Goldenberg A, Matone J, Marcondes W, Herbella FAM, Farah JFM. Comparative study of inflammatory response and adhesions formation after fixation of different meshes for inguinal hernia repair in rabbits. Acta Cir Bras. 2005;20:347-52.

2. Aydos RD, Silva IS, Goldenberg S, Goldenberg A, Simões MJ, Takita LC, Nigro AJT. Estudo comparativo do efeito das telas de politetrafluoroetileno expandido e de polipropileno, colocadas por laparoscopia, em hérnias ventrais produzidas em coelhos. Acta Cir Bras. 1999;14(2). Disponível em www.scielo.br/acb. 3. Brandão SC, Goldenberg S, Goldenberg A, Amaral DM, Pias VMS, Portella AO. Efeitos da tela de politetrafluoroetileno expandido colocada no espaço pré-peritoneal por vídeolaparoscopia em suínos. Acta Cir Bras.1998;13(3). Disponível em www.scielo. br/acb.

4. Karahasanoglu T, Onur E, Baca B, Hamzaoglu I, Pekmezci S, Boler DE, Kilic N, Altug T. Spiral tacks may contribute to intra-abdominal adhesion formation. Surg Today. 2004;34:860-4.

5. Eriksen JR, Bech JI, Linnemann D, Rosenberg J. Laparoscopic intraperitoneal mesh fixation with fibrin sealant (Tisseel) vs. titanium tacks: a randomised controlled experimental study in pigs Hernia. 2008;12:483-91.

6. Gungor B, Malazgirt Z, Topgül K, Gök A, Bilgin M, Yürüker S. Comparative evaluation of adhesions to intraperitoneally placed fixation materials: a laparoscopic study in rats: adhesions to fixation materials.Indian J Surg. 2010;72:475-80.

7. Joels CS, Matthews BD, Kercher KW, Austin C, Norton HJ, Williams TC, Heniford BT. Evaluation of adhesion formation, mesh fixation strength, and hydroxyproline content after intraabdominal placement of polytetrafluoroethylene mesh secured using titanium spiral tacks, nitinol anchors, and polypropylene suture or polyglactin
910 suture. Surg Endosc. 2005;19:780-5.

8. Byrd JF, Agee N, Swan RZ, Lau KN, Heath JJ, Mckillop IH, Sindram D, Martinie JB, Iannitti DA. Evaluation of absorbable and permanent mesh fixation devices: adhesion formation and mechanical strength. Hernia. 2011;15:553-8.

\section{Correspondence:}

Alberto Goldenberg

Rua Brigadeiro Armando Trompowsky, 705

05655-050 São Paulo - SP Brasil

Tel.: (55 11)2151-5214

Fax: $(55$ 11)3746-7363

goldenb@terra.com.br

Received: February 18, 2012

Review: April 14, 2012

Accepted: May 16, 2012

Conflict of interest: none

Financial source: none

${ }^{1}$ Research performed at experimental laboratory of Albert Einstein Teaching and Research Institute, Sao Paulo, Brazil. 